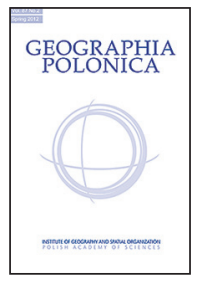

\title{
EAST-CENTRAL EUROPEAN HUMAN GEOGRAPHERS IN ENGLISH-DOMINATED, ANGLOPHONE-BASED INTERNATIONAL PUBLISHING SPACE
}

\author{
Artur Bajerski ${ }^{1}$ - Krzysztof Przygoński \\ ${ }^{1}$ Institute of Socio-Economic Geography and Spatial Management \\ Adam Mickiewicz University \\ Dzięgielowa 27, 61-680 Poznań: Poland \\ e-mail: bajerski@amu.edu.pl
}

${ }^{2}$ Department of Linguistic Applications in Management

Czestochowa University of Technology

Armii Krajowej 19 B, 42-200 Częstochowa: Poland

e-mail: k.przygonski@wp.pl

\begin{abstract}
A number of investigations have recently been devoted to the issues of inequalities in the international academic discourse. Hardly any of them concern, though, scholarly publishing practices and the actual utilization of the scientific output of non-Anglophone geographers, especially those from regions undergoing a neoliberal turn in the management of tertiary education and science. The following article aims to partly fill the gap through a close bibliometric analysis of the participation of researchers from East-Central Europe in international human geography. The investigation makes use of information about articles published in 48 geographical journals indexed in Web of Science. The results of the examination reveal that the share of researchers from East-Central Europe in the international geographical discourse is rather inconsiderable. The geographers struggle with the following problems: (1) publishing in a limited group of periodicals (concerning mostly the issues of Europe) coupled with a dearth of publications in important American and British societal journals as well as the ones of a more radical orientation; (2) infrequent citations of their works as compared to those of Anglophone and Western European researchers. All this is accounted for, inter alia, by (1) the negative impact the socialist period had on the development of social sciences, (2) a poor command of English, (3) a research focus on well-established and 'safe' themes as well as (4) the mechanisms of the Anglophone dominance in science. Giving all these handicaps careful consideration, the authors formulate the idea of doublepublication policy aimed at ameliorating the discussed problems.
\end{abstract}

\section{Key words}

East-Central Europe - geographers - bibliometric analysis - scientific communication - Anglophone domination - English language 


\section{Introduction: Anglophone dominance and non-Anglophone researchers in international human geography}

In recent years, one may easily discern a world-wide trend of the neoliberalisation of academic and science management. Passi (2005) defined it as changing conditions of knowledge creation which are largely characterized by internationalization and competition. National scientific societies and state committees seem to have, almost unanimously, adopted the competitive model of science management. Research funds, which used to be distributed on the basis of the number of scientific staff, are now allocated by far less evenly; i.e. by means of calculating 'research output'. The majority of state funds on scientific research has been shifted from research subsidies to research grants. This state of affairs is aptly delineated by Aalbers and Rossi (2009: 119-120) who point out that:

"The introduction of centralized or multilevel assessment systems and of the related governance structures, along the lines of the Research Assessment Exercises adopted in Britain since the mid-1980s, brings about profound changes in the ways in which research is undertaken by human geographers in an increasing number of countries: academic entrepreneurialism and publishing practices centered on the central role of impact-factor journals are the distinguishing features of the changing university systems in Western Europe and many other countries inclined to adopt the neoliberal recipes of societal governance."

The implementation of this neoliberal model of science management seems to have posed a considerable challenge in the non-English speaking countries, especially in regions not fully integrated with the Anglophone science. This is particularly the case in East-Central Europe (the Czech Republic, Hungary, Poland and Slovakia) which, in order to boost the competitiveness among its scholars and make their research more international, reformed over a couple of past years its system of tertiary education and science. This situation seems to pose an especially great challenge to human geographers who, until quite recently, did not participate widely in the international scientific discourse. The low level of the internationalization of research and difficulties in having their papers published in journals of an international range are regarded by the geographers from East-Central Europe (ECE) themselves as some of the greatest weaknesses of the local geography (e.g. Łoboda 2004; Siwek 2010; Bański 2015).

- An analysis of the condition of ECE geographers must not be carried out in isolation from the broader problem of the general Anglophone dominance in geography and science. A lively body of literature on the topic shows that non-Anglophone researchers are under-represented and marginalized. The marginalization takes place through the following:

- language barriers (difficulties with parallel publishing in a national language and in English, the issues of second language competence, untranslatability of certain terms, the costs of translation, etc. - Aalbers 2004; Aalbers \& Rossi 2009; Kitchin 2005; Minca 2003; Paasi 2005; Simonsen 2004; Vaiou 2004; Bański 2013);

- an inadequacy of the English language to express precisely the meanings of nonWestern or even non-Anglophone intellectual and cultural tradition, especially in human and social sciences (Siguan 2001);

- the present-day gate-keeping practices on the part of English and American editors, reviewers and scholars (Kaplan 2001; Siguan 2001);

- limited access to core publications (ECE universities have bought access to the journals of selected publishers only; the majority of most important research monographs written by Anglophone researchers are not available in ECE libraries - Bosman 2009); 
- the policy of editorial boards of some prominent international journals (e.g. demanding the citation of works written in English and/or by Anglophone authors, forcing articles to be anchored in the Anglophone geographical tradition - Berg \& Kearns 1998; Yeung 2001; Aalbers 2004; Vaiou 2004; Hassink 2007);

- mechanisms of scientific communication in the Anglo-American geography (e.g., a conviction about an idiographic and local character of publications by nonAnglophone geographers and rare references to them - Minca 2000; Olds \& Poon 2002; Garcia-Ramon 2003, 2004; Simonsen 2004; Vaiou 2004);

- the supremacy of the USA's scientific infrastructure which not only survived intact during the World War II but also further developed after its completion faster than anywhere else (Kaplan 2001);

- a more general economic, political and technological dominance of the USA and its being the cradle of information and storage systems developed thanks to the invention of the computer (Kaplan 2001).

The dominance of Anglophone science and the hegemony of English as the sole lingua franca of scholarly communication have numerous negative repercussions for ECE scholars in general and human geographers from the region in particular. The following issues seem to come to the fore: (1) the structuring of the international information systems according to Anglophone conceptualizations and hierarchies expressed through the medium of English; (2) threatening the existence, cultivation and/or development of scientific registers of smaller languages; (3) imposing on non-Western and non-Anglophone nations coming from different linguacultural and scholarly traditions the English point of view of the world, their categorizations of the world and, consequently, promoting American ideas and authors; (4) coercing academics to have their papers published in English in 'international' (i.e. American and British) journals (Swales 1997; Kaplan 2001; Siguan 2001; de Swaan 2001).
The above-mentioned factors continue to sustain the Anglophone dominance in human geography. According to recent research, Anglophone investigators make up circa $80-90 \%$ of all authors and editors of leading international geographical journals (Guttiérrez \& López-Nieva 2001; Short et al. 2001; Rodríguez-Pose 2004; Bański \& Ferenc 2013). Foster et al. (2007) have shown that this state of affairs is analogous if only ,ripple-making' (more than 10 citations) articles are taken account of.

International geography is highly concentrated not only on the level of countries but also on the level of scientific institutions. The top 10 most-commonly cited geographical departments ( 8 in the UK, one in Canada and one in Singapore) account for almost one-third $(30.2 \%)$ of all citations in international human geography journals (Foster et al. 2007). As regards geographers having the greatest scientific influence (measured by means of $\mathrm{H}$-index), the first non-Anglophone geographer was ranked 29th (Henry Yeung) and there were no French, German, Scandinavian or ECE geographers in the first 100 (Bodman 2010).

The situation presented above seems, at least partly, associated with the linguistic hegemony of English in modern science. Harris (2001) and Sheurmans et al. (2010) show that the role of English in international science is constantly increasing and that the language has frequently replaced various mother tongues in journals of a national range. In fact, English is also becoming the sole language used during the congresses of the International Geographical Union (Harris 2001). Non-Anglophone and non-English language geographical journals are used almost exclusively for the scientific communication within the country of their origin and/ or within a given language area. Despite the long-established traditions and the high scientific standards of many non-Anglophone journals, they cannot be regarded as truly international (Bajerski 2011).

The process of the shift to the English language and to the Anglophone theoretical 
orientation in international geography took place between 1950s and 1970s. According to Whitehand and Edmondson (1977), one could easily discern that in this period the marked drop in the usage of works written by French and German geographers by scholars from the Anglophone countries was accompanied by the rising number of citations of Anglophone works by French and German researchers.

The dominance of Anglophone researchers in international geography is also a result of specific publishing practices on the part of non-Anglophone researchers. On the one hand, they strive to have their papers published in English and, on the other hand, keep publishing in their mother tongues (Minca 2000; Aalbers \& Rossi 2007; Schuermans et al. 2010; Bajerski \& Siwek 2012). Claudio Minca (2000: 287), an Italian radical geographer, depicts the situation of non-Anglophone geographers along the following lines:

"[They] are forced continually and inescapably to dialogue/work on two parallel levels within the context of their own national geographies, with their rules, logics, and languages, but also within the broader international (read Anglo-American) context, with its own logics and its own particular lingua franca. This constant mediation between two (if not more) academic universes, I believe, is the condition of many Finnish, German, Italian, Spanish, and Swiss geographers (among many others)"

Trying to work in different contexts and write for different audiences is not a too efficient way of distributing one's research results. The analysis of the most-widely cited publications by Czech geographers reveals that international and domestic publications are aimed at different readerships and that they perform different functions. The English-language articles published by Czech authors in international journals are almost exclusively cited by non-Czech researchers, with a minimal number of citations by Czech geographers. By contrast, books and articles published in the Czech Republic serve as a medium of the exchange of information for almost exclusively Czech geographers (Bajerski \& Siwek 2012).

Apart from this quite unique research, we still know very little about the production of geographical knowledge in ECE countries and its transmission to international scientific community. This situation seems to constitute a part of a wider problem concerning our inadequate comprehension of the functioning of non-Anglophone geographies. In the entry for 'Anglophone hegemony' found in International Encyclopedia of Human Geography, one can read the following: "we still know little about the ways in which non-English-language human geographers disseminate their scientific results and are already accustomed to deal with multilevel, 'international', publishing spaces" (Aalbers \& Rossi 2009: 120).

The aim of this article is (1) to analyze the position of East-Central European human geographers in international publishing space and (2) to suggest ways to overcome, at least partially, the problem described above. Three main research questions are raised: (1) What is the extent of participation of ECE researchers in international human geography? (2) In which journals do ECE human geographers publish their articles? (3) To what degree are articles written by ECE human geographers used by foreign scientists?

\section{Methods and definitions}

A basic task in the research on the situation of human geographers in scientific communication on the international level is to define who may count as a geographer. According to Chojnicki (1984), there are two ways of understanding a scientific discipline. The first approach assumes its substantive autonomy - individual scientific disciplines analyze case-specific objects or their specific characteristics. The second approach assumes that a scientific discipline is subjectively autonomous; i.e., it is constituted by scientific practices of researchers. Linking these approaches to the definition of geography, one should discern that geography can be described either as a discipline with a unique 
research subject and one having its own unique methodology or as a discipline constituted by the society of geographers. Accordingly, a geographer may be defined either as an investigator conducting research that is specific to geography, or as a researcher belonging to the society of geographers (i.e. by working at a geographical institution). Taking into account the rising degree of interdisciplinarity in science and the popularity of interdisciplinary research teams in scientific institutions, it seems much more justifiable to define geographers as researchers doing geographical research (even if they do not work at geographical institutions).

The above-mentioned definition is easy to operationalise since the outcomes of geographical research are published in geographical journals. From this perspective, geographers are persons publishing their articles in geographical journals.

Determining as to which journals can be counted as geographical is relatively easy. This information may be found on relevant websites, editorial pages or databases indexing scientific journals. It must be noted, nevertheless, that some editors may not admit that their journals are geographical; even if they are clearly so. This seems characteristic of some journals devoted to urban research or regional studies. The geographical character of formally non-geographical journals can be easily verified by means of a citation analysis - if a journal has the strongest citation links to geographical journals, one may assume that it is most of all geographical.

In the following research, the authors refers to data concerning 48 journals. All of them have been indexed in Thomson Reuters Journal Citation Reports'. Information on the citation of the articles found therein and their authorship was derived from Thomson Reuters Web of Science database.

Out of all 48 journals included in the analysis, 38 of them formally represented the field of geography and 10 were geographical journals representing other disciplines (cho-

\footnotetext{
1 Currently Clarivate Analytics JCR.
}

sen on the basis of citation links). One must remember, however, that there were altogether as many as 62 journals listed in the category 'geography' in Journal Citation Reports 2010. Some of them were published in languages different from English, others were brought out outside Europe or the USA, and still others were journals in which human geographers did not publish. This kind of journals was useless for the analysis of the situation of ECE geographers in international science. Table 1 presents a list of the selected journals.

The analysis included articles from the years 1995-2010 which were published under the heading 'article' or 'review'. These two categories of scientific papers are the greatest influence in the world of science; i.e., one measured by means of the citation rate (Sigogneau 2000; Huang et al. 2008). They are also two the most popular types of journal papers. Further research consists of the analysis of the number and share of ECE papers in international human geography journals in the years 1995-2010 and the citations given to them in this period. The following study comprises an analysis of the number and the share of ECE papers in international human geography.

\section{Results}

The collected data show that the role played by the ECE countries has not been as important as the one by the major 'producers' of human geographical knowledge on the international level. In the years 1995-2010, there were 24,549 papers published either as an article or a review in the analyzed set of journals. Geographers from the ECE countries contributed merely 171 articles $(0.7 \%$ of all - Tab. 2). The number makes up only $2.3 \%$ of the one produced by the US and $2.6 \%$ by the UK. Interestingly, the joint number of ECE articles is comparable to that characterizing Taiwan (173 papers) or Turkey (160 articles). An individual position of the ECE countries in the global ranking ranged from 37 (Poland) to 47 (Slovakia). 
Table 1. International journals included in the analysis

\begin{tabular}{|c|c|c|c|c|c|}
\hline No. & Journal title & $\begin{array}{l}\text { Number of } \\
\text { articles in } \\
1995-2010\end{array}$ & No. & Journal title & $\begin{array}{c}\text { Number of } \\
\text { articles in } \\
1995-2010\end{array}$ \\
\hline 1 & Annals of Regional Science & 520 & 25 & $\begin{array}{l}\text { Global Networks - A Journal of } \\
\text { Transnational Affairs }\end{array}$ & 162 \\
\hline 2 & $\begin{array}{l}\text { Annals of the Association of Ameri- } \\
\text { can Geographers }\end{array}$ & 591 & 26 & Health \& Place & 624 \\
\hline 3 & Antipode & 570 & 27 & Housing Studies & 590 \\
\hline 4 & Applied Geography & 371 & 28 & $\begin{array}{l}\text { International Journal of Urban and } \\
\text { Regional Research }\end{array}$ & 732 \\
\hline 5 & Area & 594 & 29 & Journal of Economic Geography & 211 \\
\hline 6 & Cities & 555 & 30 & Journal of Geography & 432 \\
\hline 7 & Cultural Geographies & 190 & 31 & $\begin{array}{l}\text { Journal of Geography in Higher } \\
\text { Education }\end{array}$ & 389 \\
\hline 8 & Economic Geography & 244 & 32 & Journal of Historical Geography & 435 \\
\hline 9 & Environment and Planning A & 1,768 & 33 & Journal of Maps & 129 \\
\hline 10 & $\begin{array}{l}\text { Environment and Planning B-Plan- } \\
\text { ning and Design }\end{array}$ & 762 & 34 & Journal of Regional Science & 486 \\
\hline 11 & $\begin{array}{l}\text { Environment and Planning C- } \\
\text { Government and Policy }\end{array}$ & 594 & 35 & Journal of Rural Studies & 502 \\
\hline 12 & Erdkunde & 101 & 36 & Journal of Transport Geography & 201 \\
\hline 13 & $\begin{array}{l}\text { Eurasian Geography and Econom- } \\
\text { ics }\end{array}$ & 290 & 37 & Land Use Policy & 712 \\
\hline 14 & European Planning Studies & 658 & 38 & Landscape and Urban Planning & 1,203 \\
\hline 15 & $\begin{array}{l}\text { European Urban and Regional } \\
\text { Studies }\end{array}$ & 229 & 39 & Papers in Regional Science & 401 \\
\hline 16 & Gender Place and Culture & 199 & 40 & Political Geography & 569 \\
\hline 17 & Geoforum & 864 & 41 & Population Space and Place & 162 \\
\hline 18 & $\begin{array}{l}\text { Geografiska Annaler Series B- } \\
\text { Human Geography }\end{array}$ & 132 & 42 & Professional Geographer & 555 \\
\hline 19 & Geographical Analysis & 309 & 43 & Progress in Human Geography & 571 \\
\hline 20 & Geographical Journal & 296 & 44 & Regional Studies & 1,062 \\
\hline 21 & Geographical Research & 102 & 45 & $\begin{array}{l}\text { Tijdschrift voor economische en } \\
\text { sociale geografie }\end{array}$ & 617 \\
\hline 22 & Geographical Review & 531 & 46 & $\begin{array}{l}\text { Transactions of the Institute of Brit- } \\
\text { ish Geographers }\end{array}$ & 452 \\
\hline 23 & Geographische Zeitschrift & 210 & 47 & Urban Geography & 556 \\
\hline 24 & Geography & 467 & 48 & Urban Studies & 1,639 \\
\hline
\end{tabular}

Source: own compilation based on Web of Science. 
Table 2. The biggest producers of articles in selected human geographical journals (years 1995-2010)

\begin{tabular}{|c|c|c|c|c|c|}
\hline No. & Country & $\begin{array}{l}\text { Number } \\
\text { of articles }\end{array}$ & No. & Country & $\begin{array}{l}\text { Number } \\
\text { of articles }\end{array}$ \\
\hline 1 & United States & 7,478 & 26 & Taiwan & 173 \\
\hline 2 & England & 6,538 & 27 & Turkey & 160 \\
\hline 3 & Canada & 1,717 & 28 & South Korea & 154 \\
\hline 4 & Netherlands & 1,298 & 29 & Austria & 139 \\
\hline 5 & Australia & 1,068 & 30 & Greece & 137 \\
\hline 6 & Scotland & 1,056 & 31 & Portugal & 99 \\
\hline 7 & Germany & 811 & 32 & Brazil & 95 \\
\hline 8 & Wales & 623 & 33 & India & 83 \\
\hline 9 & Spain & 576 & 34 & Mexico & 81 \\
\hline 10 & Peoples Republic of China & 531 & 35 & Hong Kong & 73 \\
\hline 11 & Sweden & 432 & 36 & Russia & 68 \\
\hline 12 & France & 397 & 37 & Poland & 66 \\
\hline 13 & Italy & 380 & 38 & Estonia & 50 \\
\hline 14 & New Zealand & 358 & 39 & Czech Republic & 48 \\
\hline 15 & Israel & 306 & 40 & Chile & 43 \\
\hline 16 & Japan & 306 & 41 & Thailand & 42 \\
\hline 17 & Singapore & 277 & 42 & Hungary & 40 \\
\hline 18 & Belgium & 260 & 43 & Ghana & 27 \\
\hline 19 & South Africa & 254 & 44 & Indonesia & 25 \\
\hline 20 & North Ireland & 251 & 45 & Kenya & 23 \\
\hline 21 & Norway & 229 & 46 & Iran & 22 \\
\hline 22 & Ireland & 212 & 47 & Slovakia & 22 \\
\hline 23 & Denmark & 197 & 48 & Bangladesh & 19 \\
\hline 24 & Finland & 192 & 49 & Botswana & 19 \\
\hline 25 & Switzerland & 186 & 50 & Luxembourg & 19 \\
\hline
\end{tabular}

Source: own compilation based on Web of Science

The analysis reveals a positive rising tendency of the share of ECE geographers in international human geography in the years 1995-2010. A comparison of two-year periods shows that the share of ECE geographers rose from $0.3-0.6 \%$ in $1995-2000$ to about $1.0 \%$ in $2007-2010$. This was chiefly caused by a considerable growth in the number of publications by ECE geographers in international human geographical journals (Tab. 3). It is worth noting that this increase occurred in the period of profound changes in the sphere of the financing of science and its management in the Czech Republic, Hungary, Poland and Slovakia. In 2000s, all of these countries shifted from systems based on state subsidies to systems characterized by a central role of research grants. In some countries (e.g. Poland), the internationalization of research and other scientific practices have become a prerequisite for being awarded academic titles. 
Table 3. The share of all ECE articles in the production of human geographical papers (years 1995-2010)

\begin{tabular}{|c|c|c|c|}
\hline \multirow{2}{*}{ Years } & \multicolumn{2}{|c|}{ Number of articles } & \multirow{2}{*}{$\begin{array}{c}\text { Share of ECE } \\
\text { articles in total (\%) }\end{array}$} \\
\cline { 2 - 3 } & Total & ECE & 0.97 \\
\hline $2009-2010$ & 4,641 & 45 & 1.03 \\
$2007-2008$ & 3,895 & 40 & 0.53 \\
$2005-2006$ & 3,199 & 17 & 0.50 \\
$2003-2004$ & 2,807 & 14 & 0.73 \\
$2001-2002$ & 2,742 & 20 & 0.56 \\
$1999-2000$ & 2,509 & 14 & 0.56 \\
$1997-1998$ & 2,335 & 13 & 0.37 \\
$1995-1996$ & 2,180 & 8 & \\
\hline
\end{tabular}

Source: own compilation based on Web of Science.

One of the distinctive features of the international activity of ECE human geographers is a high concentration of their publishing in a relatively small set of journals. 10 journals with the highest share of ECE articles account for $57 \%$ of its total number
(98 of 171 articles). 10 journals with the highest number of ECE articles account for $65 \%$ respectively (Tab. 4).

The most popular human geographical journals among ECE researchers were Landscape and Urban Planning (24 articles), Euro-

Table 4. The number and share of ECE articles in selected geographical journals in 1995-2010 (\%)

\begin{tabular}{|c|c|c|c|c|}
\hline \multirow{3}{*}{ No. } & \multirow{3}{*}{ Journal } & \multicolumn{3}{|c|}{ Articles in 1995-2010 } \\
\hline & & \multirow{2}{*}{ Total number } & \multicolumn{2}{|c|}{ ECE countries } \\
\hline & & & Number & $\%$ of total number \\
\hline 1 & European Urban and Regional Studies & 229 & 15 & 6.55 \\
\hline 2 & Geografiska Annaler Series B-Human Geography & 132 & 3 & 2.27 \\
\hline 3 & Environment and Planning C-Government and Policy & 594 & 13 & 2.19 \\
\hline 4 & Landscape and Urban Planning & 1,203 & 24 & 2.00 \\
\hline 5 & Tijdschrift voor economische en sociale geografie & 617 & 10 & 1.62 \\
\hline 6 & European Planning Studies & 658 & 10 & 1.52 \\
\hline 7 & International Journal of Urban and Regional Research & 732 & 11 & 1.50 \\
\hline 8 & Global Networks - A Journal of Transnational Affairs & 162 & 2 & 1.23 \\
\hline 9 & Population Space and Place & 162 & 2 & 1.23 \\
\hline 10 & Land Use Policy & 712 & 8 & 1.12 \\
\hline 11 & Cities & 555 & 6 & 1.08 \\
\hline 12 & Eurasian Geography and Economics & 290 & 3 & 1.03 \\
\hline 13 & Papers in Regional Science & 401 & 4 & 1.00 \\
\hline 14 & Journal of Transport Geography & 201 & 2 & 1.00 \\
\hline
\end{tabular}




\begin{tabular}{|c|c|c|c|c|}
\hline 15 & Erdkunde & 101 & 1 & 0.99 \\
\hline 16 & Economic Geography & 244 & 2 & 0.82 \\
\hline 17 & Health \& Place & 624 & 5 & 0.80 \\
\hline 18 & Journal of Maps & 129 & 1 & 0.78 \\
\hline 19 & Housing Studies & 590 & 4 & 0.68 \\
\hline 20 & Regional Studies & 1,062 & 7 & 0.66 \\
\hline 21 & Journal of Rural Studies & 502 & 3 & 0.60 \\
\hline 22 & Applied Geography & 371 & 2 & 0.54 \\
\hline 23 & Journal of Geography in Higher Education & 389 & 2 & 0.51 \\
\hline 24 & Gender Place and Culture & 199 & 1 & 0.50 \\
\hline 25 & Urban Studies & 1,639 & 8 & 0.49 \\
\hline 26 & Geoforum & 864 & 4 & 0.46 \\
\hline 27 & Journal of Regional Science & 486 & 2 & 0.41 \\
\hline 28 & Environment and Planning B- Planning and Design & 762 & 3 & 0.39 \\
\hline 29 & Political Geography & 569 & 2 & 0.35 \\
\hline 30 & Geographical Journal & 296 & 1 & 0.34 \\
\hline 31 & Journal of Historical Geography & 435 & 1 & 0.23 \\
\hline 32 & Environment and Planning A & 1,768 & 4 & 0.23 \\
\hline 33 & Transactions of the Institute of British Geographers & 452 & 1 & 0.22 \\
\hline 34 & Geography & 467 & 1 & 0.21 \\
\hline 35 & Annals of Regional Science & 520 & 1 & 0.19 \\
\hline 36 & Geographical Review & 531 & 1 & 0.19 \\
\hline 37 & Progress in Human Geography & 571 & 1 & 0.18 \\
\hline 38 & Annals of the Association of American Geographers & 591 & 0 & 0.00 \\
\hline 39 & Antipode & 570 & 0 & 0.00 \\
\hline 40 & Area & 594 & 0 & 0.00 \\
\hline 41 & Cultural Geographies & 190 & 0 & 0.00 \\
\hline 42 & Geographical Analysis & 309 & 0 & 0.00 \\
\hline 43 & Geographical Research & 102 & 0 & 0.00 \\
\hline 44 & Geographische Zeitschrift & 210 & 0 & 0.00 \\
\hline 45 & Journal of Economic Geography & 211 & 0 & 0.00 \\
\hline 46 & Journal of Geography & 432 & 0 & 0.00 \\
\hline 47 & Professional Geographer & 555 & 0 & 0.00 \\
\hline 48 & Urban Geography & 556 & 0 & 0.00 \\
\hline
\end{tabular}

Source: own compilation based on Web of Science.

pean and Urban Studies (15), Environment and Planning C (13), International Journal of Urban and Regional Research (11), Tijdschrift voor economische en sociale geo- grafie (10) and European Planning Studies (10). In general, the above-mentioned journals as well as Swedish Geografiska Annaler Series B-Human Geography are character- 
ised by the biggest share of ECE authors. ECE geographers were the most active on the forum of European Urban and Regional Studies which account for $6.5 \%$ of the articles published in the period 1995-2010.

The analysis of the journals in which ECE geographers publish their papers enables to single out a couple of distinguishing characteristics of their international publishing activity in the years 1995-2010. The first one relates to their infrequent publishing in topranked journals. All in all, they published only 4 articles in top-ranked journals (IF $>3$; Economic Geography, Progress in Human Geography, Transactions of the Institute of British Geographers, and Journal of Economic Geography). The second one concerns their tendency to publish in the journals devoted to social and economic issues of Europe: European Urban and Regional Studies, Geografiska Annaler Series B-Human Geography, Tijdschrift voor economische en sociale geografie and European Planning Studies. The third characteristic refers to ECE geographers' very infrequent publishing in American and British societal journals. ECE geographers published only 2 articles in the journals of Royal Geographical Society (Area, The Geographical Journal, Transactions of the Institute of British Geographers) and no articles at all in the journals of Association of American Geographers (Annals of the Association of American Geographers, Professional Geographer). The last one reveals ECE geographers' lack of interest in having their papers published in radically-oriented journals (four papers in Geoforum, one in Gender Place and Culture and no papers in Antipode).

Taking the above into consideration, one may surmise that there is an under-average international usage of articles written by ECE geographers. This has been verified by the analysis of the average citation rate of articles published by researchers from various countries and East-Central Europe.

The analysis demonstrated that the mean citation rate of articles written by ESE human geographers amounted to $55-60 \%$ of the one of Anglophone researchers' and to $80-90 \%$ of the one concerning geographers from Western Europe. A comparison of the citation statistics of the two categories of articles (written with a foreign co-author and without one) has shown that the under-average citation of ESE human geographers results from the low citation rate of papers published without international co-authorship. The citation rate of such papers accounted for merely 35-40\% of Anglophone and 60-70\% of Western European researchers' citations. The mean citation rate of ECE articles coauthored internationally did not differ significantly from the statistics concerning the articles of their Western European colleagues and it amounted to $80-90 \%$ of Anglophone geographers' citations (Tab. 5).

The observation that articles prepared by international groups of authors receive far more citations than those written by individual researchers from a single country is a well-known one in scientometrics (Narin \& Whitlow 1990; Narin et al. 1991; Glänzel 2001; Leta \& Chaimovich 2002; Inzelt et al. 2009). Nevertheless, the difference in the mean citation rate in the case of ECE human geographers is extraordinary due to its being much greater than the one to be found in the case of other countries. One of the reasons for this situation are differences in citations by Anglophone researchers. A more detailed citation analysis has revealed that Anglophone researchers (in this case just the ones from the US, the UK and Canada) give far more citations to ECE papers written with an international co-authorship. This kind of articles has received $230 \%$ more citations than the articles that were not internationally co-authored (Tab. 6).

This state of affairs may be explained only partially by the reference to the so called national bias in science; i.e., a tendency to publish primarily in national periodicals (for 'a national publishing bias' see, for instance, Borry et al. 2006; Kao 2009), and to cite colleagues from the same country ('national citation bias' - Grange 1999; Møller 1990; Pasterkamp et al. 2007). The national citation bias explains why internationally co-authored 
Table 5. Articles published by ECE geographers in 1995-2010 and their citations until 2011 (a comparison with geographers from selected countries)

\begin{tabular}{|l|c|c|c|r|r|r|r|r|c|}
\hline \multirow{2}{*}{ Country } & \multicolumn{4}{|c|}{ Total } & \multicolumn{3}{c|}{ Without a foreign co-author } & \multicolumn{3}{|c|}{ With a foreign co-author } \\
\cline { 2 - 10 } & articles & citations & $\begin{array}{c}\text { citations } \\
\text { per article }\end{array}$ & articles & citations & $\begin{array}{r}\text { citations } \\
\text { per article }\end{array}$ & articles & citations & $\begin{array}{c}\text { citations } \\
\text { per article }\end{array}$ \\
\hline United States & 7,478 & 66,113 & 8.84 & 6,326 & 55,719 & 8.81 & 1,152 & 10,394 & 9.02 \\
Great Britain & 8,029 & 79,599 & 9.91 & 6,586 & 67,118 & 10.19 & 1,443 & 12,481 & 8.65 \\
Canada & 1,717 & 14,195 & 8.27 & 1,292 & 10,040 & 7.77 & 425 & 4,155 & 9.78 \\
Netherlands & 1,298 & 9,642 & 7.43 & 956 & 6,685 & 6.99 & 342 & 2,957 & 8.65 \\
Australia & 1,068 & 7,470 & 6.99 & 781 & 5,284 & 6.77 & 287 & 2,186 & 7.62 \\
Germany & 811 & 5,016 & 6.18 & 604 & 3,620 & 5.99 & 207 & 1,396 & 6.74 \\
Spain & 576 & 3,191 & 5.54 & 439 & 2,122 & 4.83 & 137 & 1,069 & 7.80 \\
China & 531 & 3,688 & 6.95 & 291 & 1,999 & 6.87 & 240 & 1,689 & 7.04 \\
Sweden & 432 & 2,722 & 6.30 & 310 & 1,816 & 5.86 & 122 & 906 & 7.43 \\
France & 397 & 2,587 & 6.52 & 238 & 1,196 & 5.03 & 159 & 1,391 & 8.75 \\
Italy & 380 & 2,605 & 6.86 & 241 & 1,400 & 5.81 & 139 & 1,205 & 8.67 \\
ECE & $\mathbf{1 7 1}$ & $\mathbf{9 2 8}$ & $\mathbf{5 . 4 3}$ & $\mathbf{9 8}$ & $\mathbf{3 6 0}$ & $\mathbf{3 . 6 7}$ & $\mathbf{7 3}$ & $\mathbf{5 6 8}$ & $\mathbf{7 . 7 8}$ \\
\hline
\end{tabular}

Source: own compilation based on Web of Science.

Table 6. The citations (until 2011) of articles published by ECE geographers in 1995-2010 according to groups of countries

\begin{tabular}{|l|c|c|c|c|c|}
\hline \multirow{2}{*}{ Type of article } & \multirow{3}{*}{ Articles } & \multicolumn{4}{|c|}{ Citing articles by researchers from: } \\
\cline { 3 - 6 } & & \multicolumn{3}{|c|}{ ECE countries } & \multicolumn{2}{|c|}{ UK + US + CANADA } \\
\cline { 3 - 6 } & & total & per one published article & total & per one published article \\
\cline { 3 - 6 } & & & & 103 & 1.05 \\
without foreign author & 98 & 77 & 0.79 & 0.67 & 3.41 \\
with foreign author & 73 & 49 & & 0.679 & \\
\hline
\end{tabular}

Source: own compilation based on Web of Science

publications are much more widely cited than the others, but it does not account for the specific position of ECE human geographers. It cannot be explained by a thematic orientation of papers either - the majority of articles by ECE human geographers (both written with and without international co-authorship) are devoted to East-Central Europe. The reason for the difference in Anglophone citations may lie in the role of Anglophone co-authors and their perception of the articles written by ECE researchers. Timár (2004) and Simonsen (2004) point to a widespread conviction on the part of Anglophone researchers that articles prepared outside of the Anglophone world are of purely empirical character and as such they do not help advance theories, which remains in their view the domain of Anglo-American geography. Considering the research results presented above, one 
may regard this symbolic marginalization of non-Anglophone researchers as partly justifiable. The low mean citation rate of the articles written by ECE human geographers (the ones without international co-authorship) may arise from their frequently empirical character or loose relations to Anglophone theories.

\section{Conclusions and discussion}

The research presented in this article reveals that East-Central European (ECE) geographers did not participate actively in the international scientific debate in human geography in the period 1995-2010. The share of ECE articles in international geographical journals reaches the level of around 1\%. This insignificant role in international geography seems to be a consequence of long decades of ECE scholars' functioning in state socialist countries. Even after 20 years after the collapse of the socialist system, ECE countries still reveal a rather low development of social sciences and a poor level of a command of foreign languages. An insufficient proficiency in English seems to be an underlying and immediate cause of the poor internationalization of ECE human geographers' research. The survey results by Eurobarometer published in 2012 in a report "Europeans and their languages" clearly indicate that the citizens of ECE countries still know the English language the worst of all members of the EU. This is also a problem that scholars (including geographers) are all too frequently grappling with on everyday basis. A poor knowledge of English was also designated by Czech and Polish geographers as a serious impediment to their participation in the international scholarly discourse (Łoboda 2004; Siwek 2010).

It is noteworthy, yet, that a positive change in the share of ECE publications in international geographical journals has been noticeable for some time now and that one may expect a more intensive participation of ECE human geographers in international scientific debate in the years to come. This is associated with a neoliberal turn in the management of higher education and science in East-Central Europe which started at the beginning of the 21st century. The process originated in the UK and the US in the 1980s has changed our way of understanding the role of universities and other institutions of higher education. Its emergence was possible thanks to shifting the stress from an intellectual inquiry to measured scientific production and performance indicators (Olssen \& Peters 2005; Deem et al. 2007). Regardless of the controversies related to 'measuring' science and then allocating financial resources on the basis of scientific output, the method in itself seems to be an effective means for integrating ECE human geographies into international science. The history of Western European non-Anglophone human geographical communities confirms the above-mentioned assumption (Paasi 2005; Aalbers \& Rossi 2007; Shuermans et al. 2010).

Results of the research presented in this article reveal that the scientific communication between ECE human geographers and a wider international audience is concentrated in a limited number of journals. ECE geographers are mostly authors of papers brought out in periodicals devoted to social and economic issues in Europe and they rarely publish in prominent and influential (American and British) societal journals or the ones of radical orientation which both play an important role in international geography. The reasons for this state of affair is that ECE human geographies are not as large and multi-layered as Anglophone geography. Some analyses of internal scientific communication in Czech and Polish geographies (Śleszyński 2009; Bajerski \& Siwek 2012) indicate that in the first decade of the 21st century the most-widely cited scholarly works were books and papers on the theory of settlement systems, economic regions, as well as the ones concerning the problems of urban areas, post-socialistic transformation and regional development. The dominance of these wellestablished research areas in ECE human geographies is not only a legacy of the socialistic period but also a direct consequence 
of key development problems which arose in the years of socio-economic transition after 1989. During the transformation period, the main task of social sciences was to grasp the rapid changes taking place then and; frequently, no time was left for sophisticated debates and multi-layered social analyses.

The above analysis demonstrated that the articles by ECE human geographers are less commonly cited than those written by their Anglophone or Western European colleagues. First of all, this seems to result from a small number of citations of articles written without international co-authorship. The research results reveal that internationally co-authored articles by ECE geographers received almost 250\% more Anglophone citations per article than those without foreign co-authorship. One may think that articles by ECE geographers written without foreign co-authors may not be sufficiently 'Anglophone' to be internationally recognized Timár 2004). The under-average use of ECE articles may also be accounted for by a peculiar bias against non-Anglophone geographies; i.e., a common belief among Anglophone researchers that articles contributed by non-Anglophone geographers have little value (Minca 2000; Timár 2004; Vaiou 2004; Simonsen 2004; Aalbers \& Rossi 2009).

Despite many positive aspects of publishing internationally co-authored articles, so high a share of such papers may in itself point to some problems of individual scholars to have their works accepted for publication. The mean share of internationally coauthored papers amounts to $15-18 \%$ in the case of British and American human geographers and 24-28\% for other Anglophone (Canada and Australia) and Germanic countries (Germany, the Netherlands, Sweden - Tab. 6). Corresponding figures for EastCentral European human geography account for $43 \%$, which is almost equal to French and Spanish geography. A small share of ECE publications in international geography (less than $1 \%$ ) and a high share of international coauthorship may indicate that the unassisted publishing in high-impact international jour- nals is still a challenge for many ECE human geographers. The aforesaid situation requires from ECE geographers to face numerous problems related to working simultaneously on two levels (Minca 2000): within their own geographies and within the broader international context. The rising share of ECE articles in international human geographical journals suggests, however, that this difficulty has been steadily overcome.

The process of integration of ECE geographers into the international scholarly debate is undeniably of great importance for both the development of geographical discourse itself and for ECE geographers whose academic work deserves international recognition. Nonetheless, in view of the above discussion, there seems to emerge a possibility that ECE scholars (just as those from any other academic discipline) may increasingly be tempted to publish mainly, or even only, in international periodicals so as to accelerate the progress of their career advancement and increase the amount of research funds allocated to the academic institutions employing them. This is actually happening in numerous countries worldwide where the dominance of English as the language of science and the competitive principles of the functioning of the scholarly world are both leading to an actual displacing of national languages, the extinction of scientific registers and limiting intranational academic discourse. In this light, it is clear that in addition to integrating ECE geographers and ECE scholars in general into the international scholarly debate, one must not forget about the need to (1) safeguard national academic registers from being displaced and (2) the need to develop national academic discussions in the mother tongue. This latter point is especially important as science is increasingly more often expected to have an applied character and such expectations definitely cannot be fully met in the local contexts if native scholars make it impossible for the national audience (not knowing specialist English well enough but potentially having the means and resources to apply the scholarly achievement of academics) to understand their discourse 
and research results. Accordingly, the integration of ECE geographers and scholars must go hand in hand with efforts put into defending smaller languages and national scholarly discourse and preventing them from the hegemony of the English language and the dominance of Anglophone science.

Importantly, it seems that just encouraging scholars to publish in native languages is not enough. They should obtain additional motivation to familiarize the local readership with their research results. A host of ECE scholars already try to publish for inter- and intranational audiences, yet, as mentioned this is not always a too effective means for the distribution of one's scholarly work. This seems to be caused by the fact that most academics active on these two fronts either (1) try to enhance their papers already published in a national language so as to prepare their better versions for the more demanding international readership or (2) abridge their articles published in international periodicals and interfere with the contents so as to have another seemingly original paper ready for the local market.

\section{References}

Aalbers M.B., 2004. Creative destruction through the Anglo-American hegemony: A non-Anglo American view on publications, referees and language. Area, vol. 36, no. 3, pp. 319-322.

Aalbers M.B., RossI U., 2007. A coming community: Young geographers coping with multi-tier spaces of academic publishing across Europe. Social \& Cultural Geography, vol. 8, no. 2, pp. 283-302.

Aalbers M.B., Rossi U., 2009. Anglo-American/ Anglophone hegemony [in:] R. Kitchin, N. Thrift (eds.) International Encyclopedia of Human Geography, vol. 1, New York: Elsevier, pp. 116-121.

BAJERSKI A., 2011. The role of French, German and Spanish journals in the scientific communication in international geography. Area vol. 43, no. 3, pp. 305-313.

BAJeRSKI A., SIwEK T., 2012. Bibliometrická analýza české geografie v databázi Scopus. Geografie, vol. 117, no. 1, pp. 52-71.
It would be much better for ECE academics and for the science itself if scholars succeeding in publishing their papers in renowned journals did not have to work twice on basically the same (but necessarily different enough) papers (which often proves a very time-consuming process) and could focus on new original projects. Nonetheless, for the sake of fostering national academic debate and protecting national academic registers, papers published in renowned international periodicals should be available also in the national languages. To make scholars and the institutions employing them interested in this 'double publication policy', they should obtain additional benefits in the form of, for example, receiving some additional 'points' for publishing a mother-tongue version of an article published abroad and counting them to some extent when 'measuring' their scientific achievements.

\section{Editors' note:}

Unless otherwise stated, the sources of tables and figures are the authors', on the basis of their own research.

BAŃSKI J., 2015. Potencjał i aktywność kadry naukowej w polskich ośrodkach geograficznych. Przegląd Geograficzny, vol. 87, no. 2, pp. 279-298.

Bański J., Ferenc M., 2013. "International" or "Anglo-American" journals of geography. Geoforum, vol. 45, pp. 285-295.

Berg L.D., Kearns R.A, 1998. America unlimited, Environment and Planning D, vol. 16 no. 2, pp. 128-132.

Bodman A.R., 2010. Measuring the influentialness of economic geographers during the 'great half century': An approach using the $h$ index. Journal of Economic Geography, vol. 10, no. 1 , pp. 141-156.

Borry P., Schotsmans P., Dierickx K., 2006. How international is bioethics? A quantitative retrospective study. BMC Medical Ethics, vol. 7, no. 1, pp. 1-6.

Bosman J., 2009. The changing position of society journals in Geography. Tijdschrift voor Economische en Sociale Geografie, vol. 100, no. 1, pp. 20-32. 
ChOJNICKI Z., 1984. Dylematy metodologiczne geografii. Przegląd Geograficzny, vol. 56, no. 3-4, pp. 3-18.

Deem R., Hillyard S., Reed M., 2007. Knowledge, higher education, and the new managerialism: The changing management of UK universities. New York: Oxford University Press.

Foster J., Muellerleile C., Olds K., Peck J., 2007. Circulating economic geographies: Citation patterns and citation behaviour in economic geography, 1982-2006. Transactions of the Institute of British Geographers, vol. 32, no. 3, pp. 295-312.

Garcia-Ramon M.D., 2003. Globalization and international geography: The questions of languages and scholarly traditions. Progress in Human Geography, vol. 27, no. 1, pp. 1-5.

Garcia-Ramon M.D., 2004. The spaces of critical geography: An introduction. Geoforum, vol. 35 no. 5, pp. 523-524.

GlÄNZEL W., 2001. National characteristics in international scientific co-authorship relations. Scientometrics, vol. 51, no. 1, pp. 69-115.

Grange R.I., 1999. National bias in citations in urology journals: Parochialism or availability? BJU International, vol. 84, no. 6, pp. 601-603.

Guttiérrez J., López-Nieva P., 2001. Are international journals of human geography really international? Progress in Human Geography, vol. 25, no. 1, pp. 53-69.

HaRRIS C.D., 2001. English as international language in geography: Development and limitations. Geographical Review, vol. 91, no. 4, pp. 675-689.

HASSINK R., 2007. It's the language stupid! On emotions, strategies, and consequences related to the use of only one language to describe and explain a diverse world. Environment and Planning $A$, vol. 39, no. 6, pp. 1282-1287.

Huang X., Xiaolan A., Yuh-Shan H., 2008. Use of citation per publication as an indicator to evaluate pentachlorophenol research. Scientometrics, vol. 75 no. 1, pp. 67-80.

Inzelt A., Schubert A., Schubert M., 2009. Incremental citation impact due to international coauthorship in Hungarian higher education institutions. Scientometrics, vol. 78, no. 1, pp. 37-43.

KAO C., 2009. The authorship and country spread of Operation Research journals. Scientometrics, vol. 78, no. 3, pp. 397-407.
KaPLAN R.B., 2001. English - the accidental language of science? [in:] U. Ammon (ed.), The dominance of English as a language of science: Effects on other languages and language communities, Berlin: Mouton de Gruyter, pp. 3-26.

KITCHIN R., 2005. Disrupting and destabilizing Anglo-American and English-language hegemony in geography. Social \& Cultural Geography, vol. 6, no. 1, pp. 1-15.

Leta J., Chaimovich H., 2002. Recognition and international collaboration: The Brazilian case. Scientometrics, vol. 53, no. 3, pp. 325-335.

ŁoBODA J., 2004. Stan i perspektywy polskiej geografii w opinii geografów. Przeglad Geograficzny, vol. 76, no. 4, pp. 389-413.

MincA C., 2000. Venetian geographical praxis. Environment and Planning D, vol. 18, no. 3, pp. 285-289.

Minca C., 2003. Critical peripheries. Environment and Planning D, vol. 21, no. 2, pp. 160-168.

Møller P.A., 1990. National citations. Nature, vol. 348, no. 6301, pp. 480.

Narin F., Whitlow E.P.P., 1990. Measurement of scientific cooperation and co-authorship in CEC-related areas of science. Vol. 1, Brussels: Commission of the European Communities.

Narin F., Stevens K., Whitlow E.P.P., 1991. Scientific co-operation in Europe and the citation of multinationally authored papers. Scientometrics, vol. 21, no. 3, pp. 313-323.

Olds K., Poon J., 2002. Theories and discourses of economic geography: Papers from Singapore Conference on Economic Geography, December 2000. Environment and Planning A, vol. 34, no. 3, pp. 379-383.

Olssen M., Peters M.A., 2005. Neoliberalism, higher education and the knowledge economy: From the free market to knowledge capitalism. Journal of Education Policy, vol. 20, no. 3, pp. 313-345.

PAASI A., 2005. Globalisation, academic capitalism, and the uneven geographies of international journal publishing spaces. Environment and Planning A, vol. 37, no. 5, pp. 769-789.

Pasterkamp G., Rotmans J.I., de Kleijn D.V.P., BORST C., 2007. Citation frequency: A biased measure of research impact significantly influenced by the geographical origin of research articles. Scientometrics, vol. 70, no. 1, pp. 153-165. 
Rodríguez-Pose A., 2004. On English as a vehicle to preserve geographical diversity. Progress in Human Geography, vol. 28, no. 1, pp. 1-4.

Schuermans N., Meeus B., De Maesschalck F., 2010. Is there a world beyond the Web of Science? Publication practices outside the heartland of academic geography. Area, vol. 42, no. 4, pp. 417-424.

Sigogneau A., 2000. An analysis of document types published in journals related to physics: Proceeding papers recorded in the Science Citation Index database. Scientometrics, vol. 47, no. 3, pp. 589-604.

SiguAN M., 2001. English and the language of science: On the unity of language and the plurality of languages [in:] U. Ammon U. (ed.), The dominance of English as a language of science: Effects on other languages and language communities. Berlin: Mouton de Gruyter, pp. 59-69.

SiMONSEN K., 2004. Differential spaces of critical geography. Geoforum, vol. 35, no. 5, pp. 525-528.

SIWEK T., 2010. Současná geografie očima českých geografü. Geografie, vol. 115, no. 4, pp. 361-376.
SWAAN DE A., 2001. English in the social sciences [in:] U. Ammon (ed.), The dominance of English as a language of science: Effects on other languages and language communities. Berlin: Mouton de Gruyter, pp. 71-83.

SWALES J.M., 1997. English as Tyrannosaurus rex. World Englishes, vol. 17, no. 3, pp. 373-382.

ŚlesZYŃSKI P., 2009. Pozycja polskich czasopism i serii geograficznych w świetle baz Google Scholar. Przeglad Geograficzny, vol. 81, no. 4, pp. 551-576.

TIMÁR J., 2004. More than 'Anglo-American', it is 'Western': hegemony in geography from Hungarian perspective. Geoforum, vol. 35, no. 5, pp. 533-538.

Whitehand J.W.R., Edmondson P.M., 1977. Europe and America. The reorientation in geographical communication in the post-war period. Professional Geographer, vol. 29, no. 3, pp. 278-282.

VAIOU D., 2004. The contested and negotiated dominance of Anglophone geography in Greece. Geoforum, vol. 35, no. 5, pp. 529-531.

YEUNG H.W., 2001. Redressing the geographical bias in social science knowledge. Environment and Planning A, vol. 33, no. 1, pp. 1-9. 